\title{
Analisis Kandungan Protein, Zat Besi dan Daya Terima Bakso Ikan Gabus dan Daging Sapi
}

\author{
Yuliana Salman ${ }^{1}$, Ermina Syainah $^{2}$, Rezkiah $^{3}$ \\ ${ }^{1,3}$ Program Studi Gizi, STIKES Husada Borneo \\ ${ }^{2}$ Poltekkes Kemenkes Banjarbaru \\ J1. A. Yani Km 30,5 No.4 Banjarbaru, Kalimantan Selatan \\ Email: salmanyuliana86@gmail.com
}

\begin{abstract}
ABSTRAK
Bakso merupakan salah satu produk olahan daging sapi dan ayam yang dibentuk seperti bola. Penelitian ini menggunakan ikan gabus yang mengandung protein 25.2 gram/100 gram dan zat besi $9 \mathrm{mg} / 100$ gram serta daging sapi yang mengandung protein 18.88 gram/100 gram dan zat besi $2.8 \mathrm{mg} / 100$ gram. Tujuan penelitian ini untuk menganalisis perbedaan kandungan protein, zat besi dan daya terima pada pembuatan bakso ikan gabus dan daging sapi. Metode yang digunakan dalam penelitian ini adalah metode eksperimen dengan menggunakan Rancangan Acak Lengkap (RAL). Penelitian ini terdiri atas 3 perlakuan dan 3 kali replikasi dengan proporsi ikan gabus dan daging sapi 60\%:40\%, 50\%:50\%, 40\%:60\%. Kadar protein diuji dengan metode kjeldhal, sedangkan kadar zat besi dengan metode ICP (Inductively Coupled Plasma). Analisis data kadar protein dan zat besi menggunakan one way anova, sedangkan untuk mutu organoleptik menggunakan analisis friedman. Hasil penelitian ini menunjukkan bahwa nilai rata-rata uji kadar protein dan zat besi tertinggi pada proporsi ikan gabus dan daging sapi (60\%:40\%) yaitu 55.65\% dan $48.50 \mathrm{ppm}$ dengan hasil uji statistik masing-masing yaitu $\mathrm{p}=0.000$ dan $p=0,001$ dengan $\alpha=0.05$, yang artinya ada perbedaan kandungan protein dan zat besi bakso dengan proporsi ikan gabus dan daging sapi yang berbeda. Pada uji daya terima yang meliputi warna, tekstur dan rasa memiliki nilai tertinggi pada proporsi ikan gabus dan daging sapi (60\%:40\%), sedangkan daya terima aroma memiliki nilai tertinggi pada proporsi ikan gabus dan daging sapi $(40 \%: 60 \%)$. Hasil uji statistik friedman menunjukkan terdapat perbedaan mutu organoleptik pada pembuatan bakso ikan gabus dan daging sapi.
\end{abstract}

Kata kunci: protein, zat besi, daya terima, ikan gabus, daging sapi

\section{Analysis of Protein Content, Iron and Acceptance of Cork Fish and Beef Meatballs}

\begin{abstract}
Meatball is one of processed products of beef and chicken that is formed like a ball. This study used cork fish that containing 25.2 gram/100 gram protein and $9 \mathrm{mg} / 100$ gram of iron and beef that containing protein $18.88 \mathrm{gram} / 100$ gram and iron $2.8 \mathrm{mg} / 100$ gram. The aims of this study was to analyze the differences in protein content, iron and acceptability of fish balls fish cork and beef. The method used in this research is an experimental method using Completely Randomized Design. The study consisted of 3 treatments and 3 replications with cork and beef proportions of 60\%:40\%, 50\%:50\%, 40\%:60\%. Protein content was tested by kjeldhal method, while iron content was by ICP (Inductively Coupled Plasma) method. Analysis of protein and iron content data using one way anova, while for acceptability data using friedman analysis. The results of this study indicate that the average value of the highest protein and iron test in the
\end{abstract}


proportion of cork and beef (60\%:40\%) is $55.65 \%$ and $48.50 \mathrm{ppm}$ with the results of statistical tests respectively $\mathrm{p}=0.000$ and $\mathrm{p}=0.001$ with $\alpha=0.05$, which means there is difference of protein content and iron meatball with different proportion of fish and cork. In the acceptance test which includes color, texture and taste have the highest value in the proportion of cork and beef (60\%:40\%), while the aroma the highest value in the proportion of cork and beef (40\%:60\%) . The result of friedman statistic test shows that there is difference of acceptability in the manufacture of fish balls of cork and beef.

Keywords: protein, iron, acceptability, cork fish, beef

\section{Pendahuluan}

Pangan dan gizi merupakan salah satu komponen penting dalam pembangunan. Komponen ini memberikan konstribusi dalam mewujudkan sumber daya manusia yang berkualitas sehingga mampu berperan secara optimal dalam pembangunan. Begitu penting perannya, pangan dan gizi dapat dianggap sebagai kebutuhan dan modal dasar pembangunan serta dijadikan indikator atas keberhasilan pangan. Penganekaragaman pangan merupakan salah satu cara memperbaiki status gizi masyarakat. Usaha penganekaragaman pangan dapat dilakukan dengan mencari bahan makanan yang baru atau bahan pangan yang sudah ada dikembangkan menjadi bahan pangan yang beranekaragam dengan harga yang relative terjangkau ${ }^{1}$.

Gizi kurang pada balita di Indonesia tahun 2010 prevalensinya sebanyak 17,9\% dan pada tahun 2013 prevalensinya meningkat menjadi $19,6 \%$. Anemia gizi besi pada balita di Indonesia tahun 2010 prevalensinya sebanyak 26,3\% dan pada tahun 2013 prevalensinya meningkat menjadi $28,1 \%$. Gizi kurang di Kalimantan Selatan pada tahun 2010 sebanyak 22,8\% dan pada tahun 2013 meningkat menjadi $27,4 \%$ sehingga perlu perhatian khusus. Sedangkan prevalensi anemia zat besi di Kalimantan Selatan Tahun 2010 sebanyak 10,9\% dan tahun 2013 meningkat menjadi $14,2 \%{ }^{2,3}$.

Mahalnya harga-harga produk pangan sumber hewani diikuti dengan meningkatnya kasus gizi kurang dan anemia gizi besi di Indonesia. Kejadian gizi kurang disebabkan oleh penyebab langsung dan tidak langsung, penyebab langsung yaitu makanan dan penyakit infeksi sedangkan penyebab tidak langsung yaitu tidak cukup tersedianya pangan, pola asuh anak yang tidak memadai dan keadaan sanitasi yang buruk ${ }^{4}$. Sedangkan kejadian anemia disebabkan oleh kebiasaan konsumsi makanan yang mengganggu penyerapan zat besi (seperti kopi dan teh) yang dikonsumsi secara bersamaan dengan makanan yang mengandung Fe, pola makan sehari-hari yang salah, kurangnya pengetahuan tentang kebutuhan zat gizi, sosial ekonomi yang rendah dan komplikasi penyakit tertentu misalnya infeksi cacingan, malaria dan talasemia ${ }^{5}$. Hal ini menyebabkan perlunya mencari alternatif sumber protein dan zat besi. Alternatif sumber protein dan zat besi yang saat ini memungkinkan untuk dikembangkan adalah ikan gabus (Ophiocephalus striatus). 
Yuliana Salman, Ermina Syainah, Rezkiah, Analisis Kandungan Protein, Zat Besi dan Daya Terima Bakso Ikan Gabus dan Daging Sapi

Ikan merupakan salah satu bahan pangan yang banyak dikonsumsi masyarakat karena banyak mengandung lemak jenuh dan protein yang berupa asam amino esensial yang penting bagi tubuh. Salah satu ikan yang memiliki kandungan tersebut adalah ikan gabus, kandungan albumin yang dimiliki ikan gabus cukup tinggi sekitar 6,2 gram dan protein 25,2 gram dalam 100 gram bahan serta zat besi $9 \mathrm{mg}$. Ikan gabus merupakan komoditas perikanan utama di Kalimantan Selatan, ikan gabus juga merupakan salah satu komoditas penentu inflasi di Kalimantan Selatan. Tingkat konsumsi ikan gabus di Kalimantan Selatan tergolong tinggi yaitu 43,3 kg per kapita per tahun ${ }^{6}$. Ikan gabus banyak hidup di air tawar dan belum dikembangkan pengolahannya dikarenakan bentuk dan aromanya yang kurang disenangi, disamping itu mudah rusak atau menurun kandungan nutrientnya setelah 4 jam lepas tangkap dan mati ${ }^{7}$.

Selain ikan, daging sapi juga sebagai salah satu dasar dalam pembuatan bakso. Daging sapi mengandung protein 18,88 gram dan zat besi 2,8 mg dalam 100 gram bahan. Zat besi merupakan mineral mikro yang paling banyak terdapat di dalam tubuh manusia dan hewan, yaitu sebanyak 3-5 gram di dalam tubuh manusia dewasa ${ }^{8}$. Kandungan gizi yang cukup tinggi pada ikan gabus dan daging sapi adalah protein dan zat besi. Zat besi mempunyai beberapa fungsi esensial di dalam tubuh, diantaranya sebagai alat angkut oksigen ke paru-paru dan jaringan tubuh, sebagai alat angkut elektron di dalam sel dan sebagai bagian terpadu berbagai reaksi enzim di dalam jaringan tubuh. Sedangkan fungsi protein di dalam tubuh diantaranya sebagai sumber energi, pertumbuhan, mengatur keseimbangan air dan pembentukan antibodi ${ }^{8}$.

Bakso merupakan salah satu produk olahan daging secara tradisional, yang sangat terkenal dan digemari oleh semua lapisan masyarakat dan bisa diharapkan sebagai sumber pangan yang cukup bergizi. Bahan baku pembuatan bakso dapat berasal dari berbagai daging lainnya antara lain, sapi, ayam dan ikan, serta ditambahkan bahan pengikat seperti tapioka ${ }^{9}$. Ikan yang digunakan dalam pembuatan bakso bervariasi, tergantung rasa yang diinginkan. Kekenyalan dapat diatur berdasarkan tepung tapioka yang digunakan ${ }^{10}$.

Pembuatan produk bakso, tidak hanya bertumpu pada pembuatan produk yang bergizi tetapi juga dapat diterima oleh masyarakat dari segi rasa, aroma, tekstur dan warnanya. Dari latar belakang di atas maka peneliti ingin menganalisis kandungan protein, zat besi dan daya terima pada pembuatan bakso dengan perbandingan proporsi ikan gabus dan daging sapi yang berbeda.

\section{Metode Penelitian}

Penelitian ini merupakan penelitian eksperimental dengan rancangan acak lengkap $(\mathrm{RAL})^{11}$. Perlakuan dalam penelitian ini, yaitu 3 perlakuan dengan proporsi ikan 
gabus:daging sapi (60\%:40\%, 50\%:50\%, 40\%:60\%) dan 3 kali replikasi .

Penelitian di Laboratorium Gizi Sekolah Tinggi Ilmu Kesehatan Husada Borneo Banjarbaru untuk pembuatan bakso dan uji organoleptik serta Laboratorium MIPA Banjarbaru untuk analisis kadar protein dan kadar Fe. Kadar protein diuji dengan metode kjeldhal, sedangkan kadar zat besi dengan metode ICP (Inductively Coupled Plasma). Penelitian ini dilakukan pada bulan JuniAgustus 2016.

Teknik Analisa Data yang digunakan untuk uji kadar protein dan kadar zat besi menggunakan one way annova dengan $\alpha=0.05$. Untuk melihat tingkat kesukaan konsumen dilakukan dengan cara uji organoleptik. Data yang di dapat dari uji mutu organoleptik kemudian di analisa dengan uji stastik program SPSS menggunakan uji Friedman dengan $\alpha=0.05$.

\section{Hasil}

\section{Uji kadar protein}

Hasil rata-rata kadar protein yang paling tinggi terdapat pada proporsi ikan gabus dan daging sapi (60\%:40\%) dengan nilai $55.65 \%$, Jika dibandingkan dengan syarat mutu bakso ${ }^{11}$ rata-rata kadar protein bakso yang didapat sudah sesuai kandungannya yaitu minimal 9\%. Berdasarkan uji statistik one way anova diperoleh nilai $\mathrm{p}=0.000<\alpha$, artinya terdapat perbedaan kandungan protein pada pembuatan bakso ikan gabus dan daging sapi dengan proporsi yang berbeda. Hasil rata- rata kadar protein pada bakso dapat dilihat pada Tabel 1.

Tabel 1. Rata-rata Hasil Uji Kadar Protein (\%) Bakso

\begin{tabular}{cc}
\hline $\begin{array}{c}\text { Perlakuan Proporsi } \\
\text { Ikan Gabus dan Daging } \\
\text { Sapi }\end{array}$ & Nilai Rata-rata \\
\hline P1 $(60 \%: 40 \%)$ & \\
P2 $(50 \%: 50 \%)$ & 55.65 \\
P3 (40\%: $60 \%)$ & 51.80 \\
Sig. Homogenitas & 44.45 \\
Sig. Anova & $: 0.026$ \\
\end{tabular}

\section{Uji kadar zat besi (Fe)}

Hasil rata-rata kadar zat besi yang tertinggi diperoleh pada proporsi ikan gabus dan daging sapi (60\%:40\%) dengan nilai $48.50 \mathrm{ppm}$. Berdasarkan uji statistik one way anova diketahui bahwa nilai $\mathrm{p}=0.001<\alpha$, artinya terdapat perbedaan kandungan zat besi pada pembuatan bakso ikan gabus dan daging sapi dengan proporsi yang berbeda. Hasil ratarata kadar zat besi pada bakso dapat dilihat pada Tabel 2.

Tabel 2. Rata-rata Hasil Uji Kadar Zat Besi (ppm) pada Bakso

\begin{tabular}{l}
\hline $\begin{array}{c}\text { Perlakuan Proporsi } \\
\text { Ikan Gabus dan Daging } \\
\text { Sapi }\end{array}$ \\
\hline P1 $(60 \%: 40 \%)$ \\
P2 $(50 \%: 50 \%)$ \\
P3 $(40 \%: 60 \%)$ \\
$\begin{array}{l}\text { Sig. Homogenitas } \\
\text { Sig. Anova }\end{array}$ \\
Mutu Organoleptik \\
\multicolumn{2}{c}{ Dewi ${ }^{12}$ mengatakan pengujian secara } \\
organoleptik adalah pengujian secara subjektif \\
yaitu melalui pertolongan panca indera \\
manusia.
\end{tabular}


Yuliana Salman, Ermina Syainah, Rezkiah, Analisis Kandungan Protein, Zat Besi dan Daya Terima Bakso Ikan

1. Warna

Berdasarkan Tabel 3 dapat diketahui bahwa nilai rata-rata penerimaan panelis terhadap warna bakso yang mendapat nilai tertinggi adalah pada perlakuan P1 dengan nilai rata-rata 3.32 dalam kategori suka. Sedangkan nilai terendah terdapat pada perlakuan $\mathrm{P} 3$ dengan nilai rata-rata 2.72 dalam kategori suka. Hasil uji statistik friedman menunjukan nilai probabilitas sebesar $0.002<\alpha$, maka menunjukan adanya perbedaan.

Tabel 3. Rata-rata Tingkat Kesukaan Warna Panelis Terhadap Bakso

\begin{tabular}{cc}
\hline \multicolumn{2}{c}{ Perlakuan Proporsi } \\
Ikan Gabus dan Daging \\
Sapi
\end{tabular}

2. Aroma

Berdasarkan Tabel 4 dapat diketahui bahwa nilai rata-rata penerimaan panelis terhadap aroma bakso yang mendapat nilai tertinggi adalah pada perlakuan P3 dengan nilai rata-rata 3.12 dalam kategori suka.

Tabel 4. Rata-rata Tingkat Kesukaan Aroma Panelis Terhadap Bakso

\begin{tabular}{cc}
\hline $\begin{array}{c}\text { Perlakuan Proporsi } \\
\text { Ikan Gabus dan Daging } \\
\text { Sapi }\end{array}$ & Nilai Rata-rata \\
\hline P1 $(60 \%: 40 \%)$ & \\
P2 $(50 \%: 50 \%)$ & 2.64 \\
P3 $(40 \%: 60 \%)$ & 2.80 \\
\hline
\end{tabular}

Sedangkan nilai terendah terdapat pada perlakuan P1 dengan nilai rata-rata 2.64 dalam kategori kurang suka. Hasil uji statistik friedman menunjukan nilai probabilitas sebesar $0.031<\alpha$, maka menunjukan adanya perbedaan.

\section{Tekstur}

Berdasarkan Tabel 3 dapat diketahui bahwa nilai rata-rata penerimaan panelis terhadap tekstur bakso yang mendapat nilai tertinggi adalah pada perlakuan P1 dengan nilai rata-rata 3.12 dalam kategori suka. Sedangkan nilai terendah terdapat pada perlakuan P3 dengan nilai rata-rata 2.48 dalam kategori kurang suka. Hasil uji statistik friedman menunjukan nilai probabilitas sebesar $0.000<\alpha$, maka menunjukan adanya perbedaan.

Tabel 5. Rata-rata Tingkat Kesukaan Tekstur Panelis Terhadap Bakso

\begin{tabular}{cc}
\hline $\begin{array}{c}\text { Perlakuan Proporsi } \\
\text { Ikan Gabus dan Daging } \\
\text { Sapi }\end{array}$ & Nilai Rata-rata \\
\hline P1 $(60 \%: 40 \%)$ & \\
P2 $(50 \%: 50 \%)$ & 3.12 \\
P3 $(40 \%: 60 \%)$ & 2.60 \\
\hline
\end{tabular}

\section{Rasa}

Berdasarkan Tabel 6 dapat diketahui bahwa nilai rata-rata penerimaan panelis terhadap rasa bakso yang mendapat nilai tertinggi adalah pada perlakuan P1 dengan nilai rata-rata 3.20 dalam kategori suka, sedangkan nilai terendah terdapat pada perlakuan P3 dengan nilai rata-rata 2.60 dalam kategori suka. Hasil uji statistik friedman menunjukan nilai probabilitas sebesar $0.003<\alpha$, maka menunjukan adanya perbedaan. 
Tabel 6. Rata-rata Tingkat Kesukaan Rasa Panelis Terhadap Bakso

\begin{tabular}{cc}
\hline $\begin{array}{c}\text { Perlakuan Proporsi } \\
\text { Ikan Gabus dan Daging } \\
\text { Sapi }\end{array}$ & Nilai Rata-rata \\
\hline P1 $(60 \%: 40 \%)$ & 3.20 \\
P2 $(50 \%: 50 \%)$ & 2.88 \\
P3 $(40 \%: 60 \%)$ & 2.60 \\
\hline
\end{tabular}

\section{Pembahasan}

\section{Uji Kadar Protein}

Protein merupakan suatu zat makanan yang amat penting bagi tubuh, karena zat ini disamping berfungsi sebagai bahan bakar dalam tubuh juga berfungsi sebagai zat pembangun dan pengatur. Sebagai bahan bakar apabila keperluan energi tidak terpenuhi oleh karbohidrat dan lemak. Sebagai zat pembangun, protein merupakan bahan pembentuk jaringan-jaringan baru yang selalu terjadi dalam tubuh. Protein mengandung unsur-unsur karbon, hidrogen, oksigen dan nitrogen yang tidak dimiliki lemak dan karbohidrat ${ }^{13}$.

Dari hasil penelitian uji protein pada tabel 1 menunjukan perlakuan pada P1 mengandung protein tertinggi yaitu sebesar $55.65 \%$ dengan proporsi $60 \%$ ikan gabus dan $40 \%$ daging sapi dibandingkan dengan perlakuan lainnya. Hal ini menunjukan bahwa semakin banyak proporsi ikan gabus yang ditambahkan, maka semakin meningkatkan kadar protein, ini disebabkan karena daging ikan gabus memiliki kandungan protein yang cukup tinggi yaitu sebesar 25.2 gram/100 gram bahan sedangkan protein yang terdapat dalam daging sapi hanya 18,88 gram/100 gram bahan ${ }^{14}$. Berdasarkan uji statistik One
Way Anova diperoleh nilai $\mathrm{p}=0.000<\alpha$, artinya terdapat perbedaan kandungan protein pada pembuatan bakso ikan gabus dan daging sapi dengan proporsi yang berbeda, sehingga dapat dilanjutkan dengan uji perbandingan ganda (tuckey) untuk melihat kombinasi perlakuan yang berbeda. Berdasarkan analisa uji tuckey didapatkan bahwa perlakuan P1 dengan P2 $\mathrm{p}=0.013<\alpha$ dan P1 dengan P3 $\mathrm{p}=0.000<\alpha$ berbeda nyata karena dalam tiap perlakuan terdapat perbedaan proporsi.

Kebutuhan protein perhari tergantung dari umur, jenis kelamin dan aktifitas fisik yaitu untuk protein balita umur 4-6 tahun dibutuhkan sebesar 35 gram $/$ hari $^{15}$, Protein yang terdapat dalam bakso pada P1 yaitu $55.65 \%$, dengan mengkonsumsi sekitar 4 butir bakso sudah dapat memenuhi kebutuhan protein sehari. Bakso pada P1 sudah memenuhi kriteria SNI bakso sebesar minimal $9 \%$.

\section{Uji Kadar Zat Besi}

Besi merupakan mineral mikro yang paling banyak terdapat di dalam tubuh manusia dan hewan, yaitu sebanyak 3-5 gram di dalam tubuh manusia dewasa. Besi mempunyai beberapa fungsi esensial dalam tubuh, sebagai alat angkut oksigen dari paruparu ke jaringan tubuh, sebagai alat angkut elektron di dalam sel, dan sebagai bagian terpadu berbagai reaksi enzim di dalam jaringan tubuh. Walaupun terdapat luas di dalam makanan banyak penduduk dunia mengalami kekurangan besi, termasuk di 
Yuliana Salman, Ermina Syainah, Rezkiah, Analisis Kandungan Protein, Zat Besi dan Daya Terima Bakso Ikan Gabus dan Daging Sapi

Indonesia. Kekurangan besi sejak tiga puluh tahun terakhir diakui berpengaruh terhadap produktivitas kerja, penampilan kognitif dan sistem kekebalan ${ }^{8}$.

Hasil uji zat besi dengan metode ICP (Inductively Coupled Plasma) pada tabel 2 menunjukan perlakuan pada P1 mengandung zat besi tertinggi yaitu sebesar $48.50 \mathrm{ppm}$ dengan proporsi $60 \%$ ikan gabus dan $40 \%$ daging sapi dibandingkan dengan perlakuan lainnya. Hal ini menunjukan bahwa semakin banyak proporsi ikan gabus yang ditambahkan, maka semakin meningkatkan kadar zat besi, ini disebabkan karena daging ikan gabus memiliki kandungan zat besi yang cukup tinggi yaitu sebesar $9 \mathrm{mg} / 100$ gram bahan sedangkan zat besi yang terdapat dalam daging sapi hanya $2.8 \mathrm{mg} / 100$ gram bahan ${ }^{6,8}$. Bentuk besi pada hewan yaitu besi-hem yang dapat diserap dua kali lipat daripada besi nonhem. Kurang lebih $40 \%$ dari besi di dalam ikan dan daging terdapat sebagai besi-hem dan selebihnya non-hem. Besi-hem merupakan bagian dari hemoglobin dan mioglobin yang terdapat dalam daging hewan ini berfungsi untuk penderita anemia gizi, karena penyebab utama anemia gizi yaitu makanan yang kurang mengandung besi, terutama dalam bentuk besi-hem ${ }^{8}$.

Berdasarkan uji statistik one way anova diketahui bahwa nilai $\mathrm{p}=0.001<\alpha$, artinya terdapat perbedaan kandungan zat besi pada pembuatan bakso ikan gabus dan daging sapi dengan proporsi yang berbeda, sehingga dapat dilanjutkan dengan uji perbandingan ganda (tuckey) untuk melihat kombinasi perlakuan yang berbeda. Berdasarkan analisa uji tuckey didapatkan bahwa perlakuan P1 dengan P2 $\mathrm{p}=0.015<\alpha$ dan $\mathrm{P} 1$ dengan P3 $\mathrm{p}=0.001<\alpha$ berbeda nyata karena dalam tiap perlakuan terdapat perbedaan proporsi.

Menurut $\mathrm{AKG}^{15}$, zat besi yang dibutuhkan perhari untuk anak-anak umur 4-6 tahun $9 \mathrm{mg} / \mathrm{hari}$, zat besi yang terdapat dalam bakso yaitu sebesar $48.50 \mathrm{ppm}$ atau $48.5 \mathrm{mg}$ melebihi kebutuhan harian zat besi, dengan mengkonsumsi sekitar 4 butir bakso dapat memenuhi kebutuhan zat besi sehari.

\section{Mutu Organoleptik}

Bakso adalah salah satu bentuk olahan restrukturisasi daging yang merupakan produk pangan berbentuk bola atau yang lain, yang diperoleh dari campuran daging/ikan yang telah dihaluskan dengan cara digiling (kadar daging/ikan minimal 50\%) dan pati atau serealia dengan atau tanpa penambahan bahan-bahan kimia lain serta bahan tambahan makanan yang diijinkan ${ }^{11}$. Secara organoleptik mutu bakso dapat di tentukan berdasarkan aspek warna, aroma, tekstur, dan rasa $^{13}$.

1. Warna

Pada P1 mempunyai warna abu-abu terang karena proporsi ikan gabus 60\%, P2 mempunyai warna abu-abu agak gelap dengan proporsi ikan gabus 50\%, dan P3 mempunyai warna abu-abu gelap dengan proporsi $40 \%$ ikan gabus. Berdasarkan tabel 3 dapat diketahui bahwa rata-rata penerimaan panelis 
terhadap warna bakso yang mendapat nilai tertinggi adalah pada perlakuan P1 dengan proporsi ikan gabus $60 \%$ dan daging sapi $40 \%$ yaitu 3.32 dengan kategori suka, sedangkan nilai terendah adalah perlakuan P3 dengan proporsi ikan gabus $40 \%$ dan daging sapi $60 \%$ yaitu 2.72 dengan kategori suka. Hal ini dikarenakan panelis lebih menyukai warna yang abu-abu terang, semakin banyak proporsi ikan gabus yang ditambahkan pada bakso semakin terang warna bakso. Hal ini disebabkan karena warna daging ikan gabus agak putih terang sedangkan warna daging sapi merah gelap. Pengaruh proporsi ikan gabus dan daging sapi terhadap daya terima warna bakso dianalisis dengan uji statistik friedman dan diperoleh $\mathrm{p}=0.002<\alpha$, yang menunjukan bahwa ada perbedaan antara proporsi ikan gabus dan daging sapi terhadap daya terima warna bakso.

\section{Aroma}

Aroma merupakan salah satu penyebab daya tarik konsumen terhadap produk pangan. Tabel 3 dapat dilihat bahwa rata-rata penerimaan panelis terhadap aroma bakso yang mendapat nilai tertinggi adalah pada perlakuan P3 dengan proporsi $40 \%$ ikan gabus dan 60\% daging sapi yaitu 3.12 dengan kategori suka sedangkan nilai terendah adalah pada perlakuan P1 dengan proporsi $60 \%$ ikan gabus dan 40\% daging sapi yaitu 2.64 dengan kategori suka. Hal ini menunjukan bahwa dengan sedikit penambahan ikan gabus pada bakso maka semakin disukai panelis.
Pengaruh proporsi terhadap mutu organoleptik aroma bakso dapat diketahui melaui uji statistik friedman. Berdasarkan uji statistik didapatkan $\mathrm{p}=0.031<\alpha \quad$ yang menunjukan bahwa ada perbedaan antara proporsi ikan gabus dan daging sapi terhadap mutu organoleptik aroma bakso pada perlakuan P1 dan P3. Penelitian terkait pemanfaatan ikan gabus menjadi bakso dalam rangka perbaikan gizi dan nilai ekonomisnya oleh Utomo ${ }^{16}$, menunjukkan bahwa kesukaan aroma tertinggi adalah perlakuan $70 \%$ tepung tapioka dan 30\% ikan gabus, sedangkan yang terendah adalah perlakuan $40 \%$ tepung tapioka dan $60 \%$ ikan gabus. Bakso dengan kadar tapioka yang cenderung tinggi lebih disukai aromanya dari pada bakso dengan kadar ikan gabus yang terlalu tinggi, hal ini karena aroma ikan gabus cenderung tajam (amis) sehingga beberapa panelis kurang suka aroma ikan akan memberikan skor rendah.

Berdasarkan pernyataan dari Gultom ${ }^{17}$ aroma merupakan suatu sensasi yang ditimbulkan oleh suatu bahan yang bercampur dengan udara sekelilingnya, tergantung dari kualitas aroma yang dimiliki dari bahan tersebut. Semakin tinggi kualitas aromanya semakin luas jangkaun untuk tercampur dengan udara sekeliling. Indra penciuman manusia berbeda-beda baik dari bentuk, dan kepekaan pengenalannya terhadap aroma. Oleh karena itu sensitifitas indra penciuman panelis harus tinggi terhadap setiap perlakuan bakso. 
Yuliana Salman, Ermina Syainah, Rezkiah, Analisis Kandungan Protein, Zat Besi dan Daya Terima Bakso Ikan Gabus dan Daging Sapi

\section{Tekstur}

Kartika dalam Surawan ${ }^{18}$ menjelaskan tekstur merupakan atribut penting dalam pengujian organoleptik. Tekstur dapat dirasakan atau diketahui bentuknya melalui sentuhan dengan indera peraba (kulit) ataupun indera perasa (lidah). Tekstur sangat berperan penting pada olahan pangan yang renyah seperti biscuit, lunak seperti daging dan kenyal seperti bakso.

Berdasarkan tabel 5 dapat dilihat bahwa rata-rata penerimaan panelis terhadap tekstur bakso yang mendapat nilai tertinggi adalah pada perlakuan P1 dengan proporsi $60 \%$ ikan gabus dan $40 \%$ daging sapi yaitu 3.12 dengan kategori suka. Hal ini disebabkan pada P1 lebih banyak ikan gabus dibandingkan daging sapi, semakin banyak ikan gabus yang ditambahkan semakin bertambah kekenyalan tekstur bakso yang dihasilkan karena tekstur ikan gabus elastis dan pada sedangkan daging sapi teksturnya agak kaku dan padat. Pengaruh proporsi terhadap mutu organoleptik tekstur bakso dianalisis dengan uji statistik friedman. Berdasarkan uji statistik diperoleh nilai $\mathrm{p}=0.000<\alpha$ yang menunjukan bahwa ada perbedaan antara proporsi ikan gabus dan daging sapi terhadap mutu organoleptik tekstur bakso.

Penelitian terkait tentang Penelitian terkait tentang studi pembuatan bakso instan dari ikan gabus oleh Zulkarnain(19), menunjukkan tekstur tertinggi yaitu pada perlakuan A1 (70\% ikan gabus dan 30\% tepung tapimal), sedangkan nilai yang terendah yaitu pada perlakuan A3 (50\% ikan gabus dan 50\% tepung tapimal). Rendahnya hasil penilain tersebut disebabkan tekstur pada A3 memiliki tekstur agak keras karena tepung yang digunakan lebih banyak pada perlakuan A1 dan A2.

4. Rasa

Rasa merupakan atribut penting dalam suatu produk atau bahan pangan. Rasa dapat diperoleh dari penambahan bumbu dan proses pengolahan. Tabel 6 dapat dilihat bahwa ratarata penerimaan panelis terhadap rasa bakso yang mendapat nilai tertinggi adalah pada perlakuan P1 dengan proporsi $60 \%$ ikan gabus dan $40 \%$ daging sapi yaitu 3.20 dengan kategori suka. Hal ini menunjukan bahwa semakin banyak penambahan ikan gabus pada bakso semakin disukai panelis.

Pengaruh proporsi terhadap mutu organoleptik rasa bakso dapat diketahui melaui uji statistik friedman. Berdasarkan uji statistik diperoleh nilai $\mathrm{p}=0.003<\alpha$ yang menunjukan bahwa ada perbedaan antara proporsi ikan gabus dan daging sapi terhadap mutu organoleptik rasa bakso. Penelitian terkait tentang studi pembuatan bakso instan dari ikan gabus oleh Zulkarnain ${ }^{19}$, menunjukkan rasa tertinggi yaitu pada perlakuan $70 \%$ ikan gabus dan $30 \%$ tepung tapimal, sedangkan nilai yang terendah yaitu pada perlakuan 50\% ikan gabus dan 50\% tepung tapimal. Dari hasil tersebut dapat dilihat produk bakso instan yang dihasikan menunjukkan tingkat kesukaan rasa yang berbeda-beda. Semakin banyak ikan gabus 
yang ditambahkan, maka semakin disukai panelis. Hal ini disebabkan rasa bakso ikan mempunyai rasa tersendiri, bakso ikan memiliki rasa yang berbeda dari bakso hasil olahan sapi dan ayam.

Rasa makanan merupakan faktor kedua yang menentukan citra rasa makanan setelah penampilan makanan itu sendiri. Apabila penampilan makanan yang disajikan merangsang saraf melalui indra penglihatan sehingga mampu membangkitkan selera untuk mencicipi makanan tersebut. Semakin enak rasa suatu produk pangan, maka semakin banyak konsumen yang menggemari produk tersebut ${ }^{13}$.

\section{Kesimpulan dan Saran}

Berdasarkan hasil penelitian ini maka dapat diambil kesimpulan sebagai berikut:

1. Kadar protein bakso tertinggi yaitu $55.65 \%$ pada perlakuan (60\% ikan gabus dan $40 \%$ daging sapi).

2. Kadar zat besi bakso tertinggi yaitu 48.50 ppm pada perlakuan $(60 \%$ ikan gabus dan $40 \%$ daging sapi).

3. Mutu organoleptik yang terdapat dalam bakso meliputi warna, aroma, tekstur, dan rasa yaitu :

a. Warna tertinggi terdapat pada proporsi (60\%:40\%) sebesar 3.32 dengan kriteria suka;

b. Aroma tertinggi terdapat pada proporsi (40\%:60\%) sebesar 3.12 dengan kriteria suka; c. Tekstur tertinggi terdapat pada proporsi P1 (60\%:40\%) sebesar 3.12 dengan kriteria suka;

d. Rasa tertinggi terdapat pada proporsi P1 (60\%:40\%) sebesar 3.20 dengan kriteria suka.

4. Ada perbedaan proporsi ikan gabus dan daging sapi terhadap kandungan protein pada bakso dengan nilai $\mathrm{p}=0.000<\alpha$.

5. Ada perbedaan proporsi ikan gabus dan daging sapi terhadap kandungan zat besi pada bakso dengan nilai $\mathrm{p}=0.001<\alpha$.

6. Ada perbedaan proporsi ikan gabus dan daging sapi terhadap daya terima pada bakso.

Proporsi terbaik dalam pembuatan bakso ikan gabus dan daging sapi yaitu $60 \%$ ikan gabus dan $40 \%$ daging sapi, karena selain memiliki kadar protein dan zat besi tertinggi juga disukai oleh panelis.

\section{Daftar Pustaka}

1. Karsin ES. Peranan Pangan dan Gizi dalam Pembangunan dalam Pengantar Pangan dan Gizi. In: Pengantar Pangan Gizi. 1st ed. Jakarta: Penebar Swadaya; 2004.

2. Badan Penelitian dan Pengembangan Kesehatan Republik Indonesia. Riset Kesehatan Dasar (RISKESDAS) 2010. 2010.

3. Badan Penelitian dan Pengembangan Kesehatan Republik Indonesia. Riset Kesehatan Dasar (RISKESDAS) 2013. Badan Penelitian dan Pengembangan 
Yuliana Salman, Ermina Syainah, Rezkiah, Analisis Kandungan Protein, Zat Besi dan Daya Terima Bakso Ikan

Kesehatan Kementerian Kesehatan RI. 2013.

4. Soekirman. Ilmu Gizi dan Aplikasinya. Jakarta: Direktorat Jenderal Pendidikan Tinggi, Departemen Pendidikan Nasional; 2000.

5. Wijanarko A. Hubungan Anemia dengan Pengetahuan Gizi, Konsumsi $\mathrm{Fe}$, Protein, Vitamin C dan Pola Haid pada Mahasiswa Putri. J Micronutr. 2012;4(1):51-8.

6. Cahyana. Ikan Gabus di Kancah Nasional Edisi 25 September-1 Oktober 2013 No.3525 Tahun XLIV. In Badan Litbang Pertanian; 2013.

7. Mayunar, Genisa A. Budidaya Ikan Kakap Putih. Jakarta: PT Grasindo; 2002.

8. Almatsier S. Prinsip Dasar Ilmu Gizi. Jakarta: Gramedia Pustaka Utama; 2009.

9. Widati AS, Widyastuti ES, Rulita, Zenny SM. No Title. J Ilmu-Ilmu Peternak. 1998;21(2):11-27.

10. Trisnaningsih D. Kadar Protein dan Betakaroten Bakso Ikan Tuna yang Diperkaya Jamur Merang (Volvariella volvaceae) dan Umbi Wortel. Universitas Muhammadiyah Surakarta; 2014.

11. Dewan Standardisasi Nasional Indonesia. SNI 01-3818-1995, Bakso Daging. Jakarta, Indonesia; 1995 p. 16.

12. Sarastani D. Penuntun Praktikum
Penilaian Organoleptik. Bogor: Jurusan Teknologi Pangan dan Gizi, Fakultas Teknologi Pertanian IPB; 2012.

13. Winarno FG. Kimia Pangan dan Gizi. Jakarta: Gramedia Pustaka Utama; 2004.

14. Suprapti L. Teknologi Pengolahan Pangan. Yogyakarta: Kanisius; 2003.

15. Departemen Kesehatan Republik Indonesia. Angka Kecukupan Gizi. Jakarta: Departemen Kesehatan Republik Indonesia; 2013.

16. Utomo D, Wahyuni R, Wiyono R. Pemanfaatan Ikan Gabus (Ophiocephalus striatus) menjadi Bakso dalam Rangka Perbaikan Gizi Masyarakat dan Upaya Meningkatkan Nilai Ekonomisnya. J Teknol Pangan. 1(1):38-55.

17. Gultom. Pengaruh Penambahan Kulit Pisang Raja terhadap Uji Daya Terima dan Nilai Gizi pada Biskuit. 2011; Available from: http://pmbpasca.ipb.ac.id

18. Surawan FED. Penggunaan Tepung Terigu, Tepung Beras, Tepung Tapioka dan Tepung Maizena terhadap Tekstur dan Sifat Sensoris Fish Nugget Ikan Tuna. J Sain Peternak Indones. 2007;2(2).

19. Zulkarnain NA. Studi Pembuatan Bakso Instan Dari Ikan Gabus. Universitas Hasanuddin; 2014. 